\title{
Odporność złączy spawanych stali 304 i 304H na korozję międzykrystaliczną
}

\author{
Resistance of welded joints 304 and 304H \\ to intercrystalline corrosion
}

\section{Streszczenie}

Stale austenityczne należą do grupy materiałów o dużym potencjale zastosowania w przemyśle energetycznym. Ze względu na przewidywaną pracę w podwyższonej temperaturze oraz środowiskach korozyjnych konieczne jest określenie odporności na korozję międzykrystaliczną złączy ze stali austenitycznych.

W artykule przedstawiono wyniki badań odporności na korozję międzykrystaliczną złączy spawanych metodą TIG ze stali 304 i 304H. Badania odporności prowadzono w roztworze $40 \%$ kwasu siarkowego (VI) i siarczanie (VI) żelaza (III), a następnie próbki były zginane zgodnie z wymaganiami normy PN-EN ISO 3651-2. Po przeprowadzonych badaniach mikroskopowych stwierdzono, że stale o strukturze austenitycznej charakteryzują się dobrą odpornością na korozję międzykrystaliczną, co dodatkowo potwierdzono badaniami strukturalnymi przy dużych powiększeniach oraz mikroanalizą składu chemicznego EDS. Na podstawie uzyskanych wyników opisano strukturę złączy spawanych ze stali 304 i 304H po badaniu odporności na korozję międzykrystaliczną.

Słowa kluczowe: stal 304; stal 304H; korozja międzykrystaliczna; spawanie TIG

\section{Abstract}

Austenitic steels belong to the group of materials with high application potential in the power industry. Due to the high working temperature and corrosive environment, it is necessary to determine the resistance to intercrystalline corrosion of austenitic steels. The paper presents the results of intergranular corrosion resistance test of TIG welded joints made of 304 and $304 \mathrm{H}$ steels. The studies were carried out in a solution of $40 \%$ sulfuric acid (VI) and iron (III) sulfate, and then the samples were bent in accordance to the requirements of PN-EN ISO 3651-2. The study has demonstrated that steels with austenitic structure are characterized by good resistance to intergranular corrosion, which was additionally confirmed by structural studies high magnification and microanalysis of chemical composition of EDS.

Basing on the obtained results the structure of steel welded joints of 304 and $304 \mathrm{H}$ steels after the intergranular corrosion resistance test has been described.

Keywords: steel 304; steel $304 \mathrm{H}$; intergranular corrosion; TIG welding

\section{Wstęp}

Rozwój sektora energetycznego wiąże się ze wzrostem zużycia energii elektrycznej na całym świecie. Powoduje to zwiększenie zużycia zarówno węgla kamiennego, jak i brunatnego w kotłach energetycznych, co wpływa niekorzystnie na środowisko poprzez zwiększenie emisji gazów cieplarnianych uwalniających się do atmosfery. Parlament Europejski w trosce o politykę klimatyczną przegłosował stanowisko w sprawie kształtu systemu reformy unijnej zezwalającej na emisję $\mathrm{CO}_{2}$. Oszacowano, że do 2021 roku zostanie wycofane $800 \mathrm{mln}$ uprawnień do emisji, co wpłynie na zwiększenie liczby źródeł odnawialnych, energooszczędność produkcji oraz poprawi bezpieczeństwo energetyczne kraju [1]. W dążeniu do realizacji założonych celów pomagać ma modernizacja obecnie używanych urządzeń, jak i tworzenie nowych bloków pracujących na parametry krytyczne i ultranadkrytyczne. Wymaga to stosowania materiałów o ulepszonych właściwościach chemicznych i fizycznych, stąd konieczność nad prowadzeniem badań nad materiałami o strukturze austenitycznej i metodami ich stałego połączenia. Od połączeń spawanych przeznaczonych dla przemysłu

Mgr inż. Katarzyna Łyczkowska, dr hab. inż. Janusz Adamiec, prof. Pol. Śl. - Politechnika Śląska, studenckie koło naukowe TECHNOMAT.

Autor korespondencyjny/Corresponding author: katarzyna.lyczkowska@polsl.pl 
energetycznego wymaga się przede wszystkim odporności na oddziaływanie środowiska korozyjnego oraz stabilność strukturalną w podwyższonej temperaturze.

Wysokie gradienty temperaturowe towarzyszące zabiegowi spawania sprzyjają procesowi rozwoju korozji międzykrystalicznej. Termin korozji międzykrystalicznej należy rozumieć jako wybiórcze rozpuszczanie granic ziaren lub przylegających obszarów wskutek procesu korozji. Wynika ono z wydzielania się węgla z przesyconego roztworu austenitu, powodując utworzenie węglików chromu $\mathrm{Cr}_{23} \mathrm{C}_{6}$ i zubożenie przygranicznych obszarów w chrom (rys. 1). Dla stali Cr-Ni, Cr-Ni-Mn odporność na korozję międzykrystaliczną spada z przyrostem węgla.

W obszarze SWC (strefa wpływu ciepła) bardzo często dochodzi do narażenia materiału na działanie krytycznego zakresu temperatur stygnięcia i obniżenia zawartości chromu poniżej poziomu $12 \%$ w stalach austenitycznych, co inicjuje proces korozji. Prowadzone badania miały za zadanie pozyskać informacje dotyczące odporności na korozję międzykry-

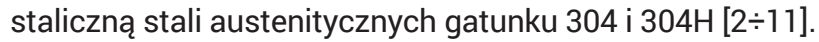

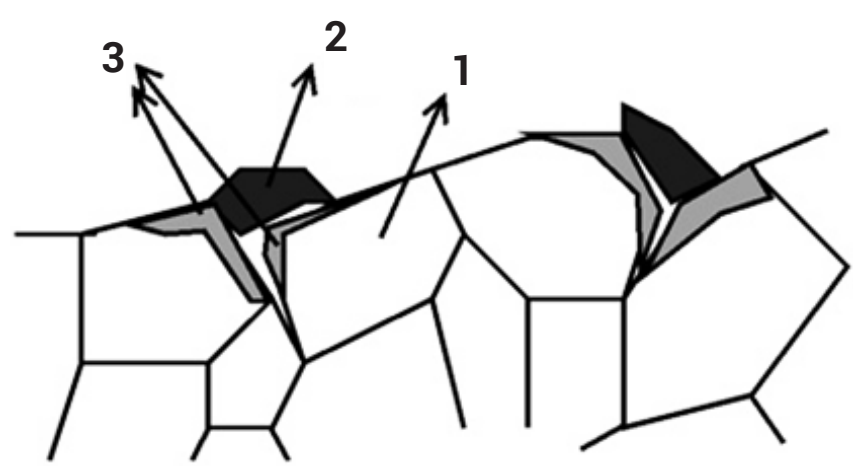

Rys. 1. Korozja międzykrystaliczna: 1 - wewnętrzny obszar ziarna, 2 - wydzielona faza, 3 - zubożony obszar [4]

Fig. 1. Intercrystalline corrosion: 1 - internal grain area, 2 - separated phase, 3 - depleted area [4]

\section{Materiał i metodyka badań}

Do badań wykorzystano blachy o wymiarach $100 \times 100 \times 3 \mathrm{~mm}$ ze stali 304 i 304H. Skład chemiczny materiałów przedstawiono w tablicy I. Blachy spawane były metodą TIG (Tungsten Inert Gas) z zastosowaniem gazu osłonowego - argonu, o przepływie $12 \mathrm{l} / \mathrm{min}$ (rys. 2).

W celu weryfikacji jakości połączenia wykonano badania wizualne zgodnie z normą PN-EN ISO 17637. Złącza spawane spełniały wymagania jakości klasy B wg PN-EN ISO 5817. Uzupełnieniem badań była ocena mikrostruktury złącza wykonana na zgładach trawionych elektrolitycznie w roztworze Lucas przy napięciu $6 \mathrm{~V}$. Wyniki obserwacji pokazano odpowiednio dla stali 304 na rysunku 3 oraz dla stali $304 \mathrm{H}$ a)

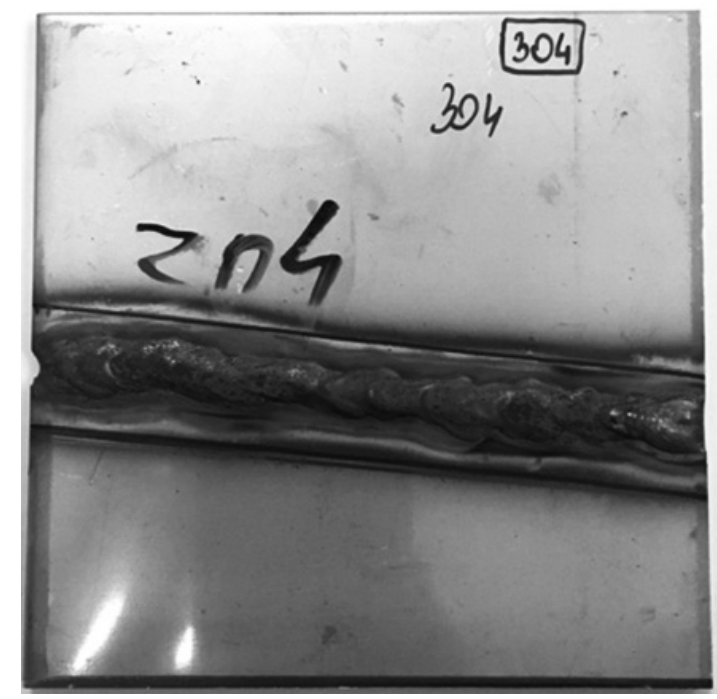

b)

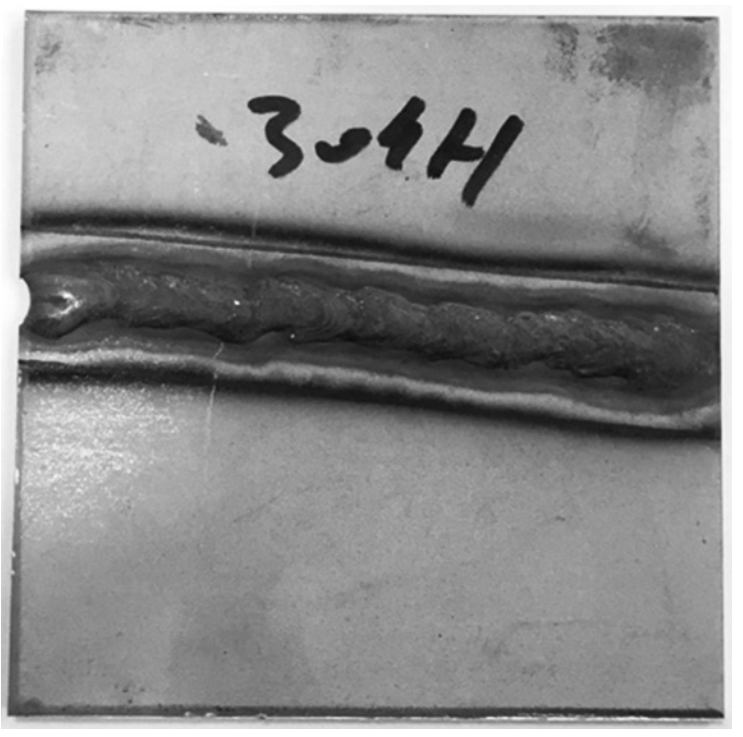

Rys. 2. Napoiny wykonane metodą TIG: a) stal 304 , b) stal $304 \mathrm{H}$ Fig. 2. TIG pad welding: a) steel 304 , b) steel $304 \mathrm{H}$

na rysunku 4. Dodatkowo wykonano mikroanalizę składu chemicznego metodą EDS z obszaru materiału rodzimego i spoiny w celu potwierdzenia jednorodności składu chemicznego (rys. 5).

Do oceny odporności na korozję międzykrystaliczną napoin ze stali 304 i $304 \mathrm{H}$ wykonano próby zgodnie z PN-EN ISO 3651-2. Wycięte spoiny zanurzone zostały

w roztworze $40 \%$ kwasu siarkowego (VI) i siarczanie żelaza (III). Roztwór podgrzano do temperatury wrzenia i próbki wytrzymano przez 24 h. Następnie napoiny były zginane na trzpieniu o kąt $120^{\circ}$ (rys. 6). W celu ujawnienia pęknięć w obszarze złącza obserwacje prowadzono od strony lica w miejscu przegięcia próbki.

Tablica I. Skład chemiczny stali 304 i $304 \mathrm{H}$

Table I. Chemical composition of 304 and $304 \mathrm{H}$ steel

\begin{tabular}{|c|c|c|c|c|c|c|c|c|c|c|c|}
\hline \multirow{2}{*}{ Stal } & \multicolumn{11}{|c|}{ Zawartość pierwiastków, \% masowe } \\
\hline & C & $\underset{\max }{\mathrm{Si}}$ & $\begin{array}{l}\text { Mn } \\
\max \end{array}$ & $\underset{\max }{P}$ & $\underset{\max }{S}$ & $\mathrm{Cr}$ & $\mathrm{Ni}$ & Nb & $\mathrm{Cu}$ & $\mathbf{N}$ & $\mathrm{Fe}$ \\
\hline 304 & 0,03 & 1,00 & 2,0 & 0,045 & 0,015 & $17,0 \div 20,0$ & $9,0-11,0$ & - & - & - & reszta \\
\hline $304 \mathrm{H}$ & 0,10 & 0,75 & 1,0 & 0,04 & 0,01 & $17,0 \div 20,0$ & $7,5-10,5$ & $0,3 \div 0,6$ & $2,5 \div 3,5$ & $0,05 \div 0,12$ & reszta \\
\hline
\end{tabular}



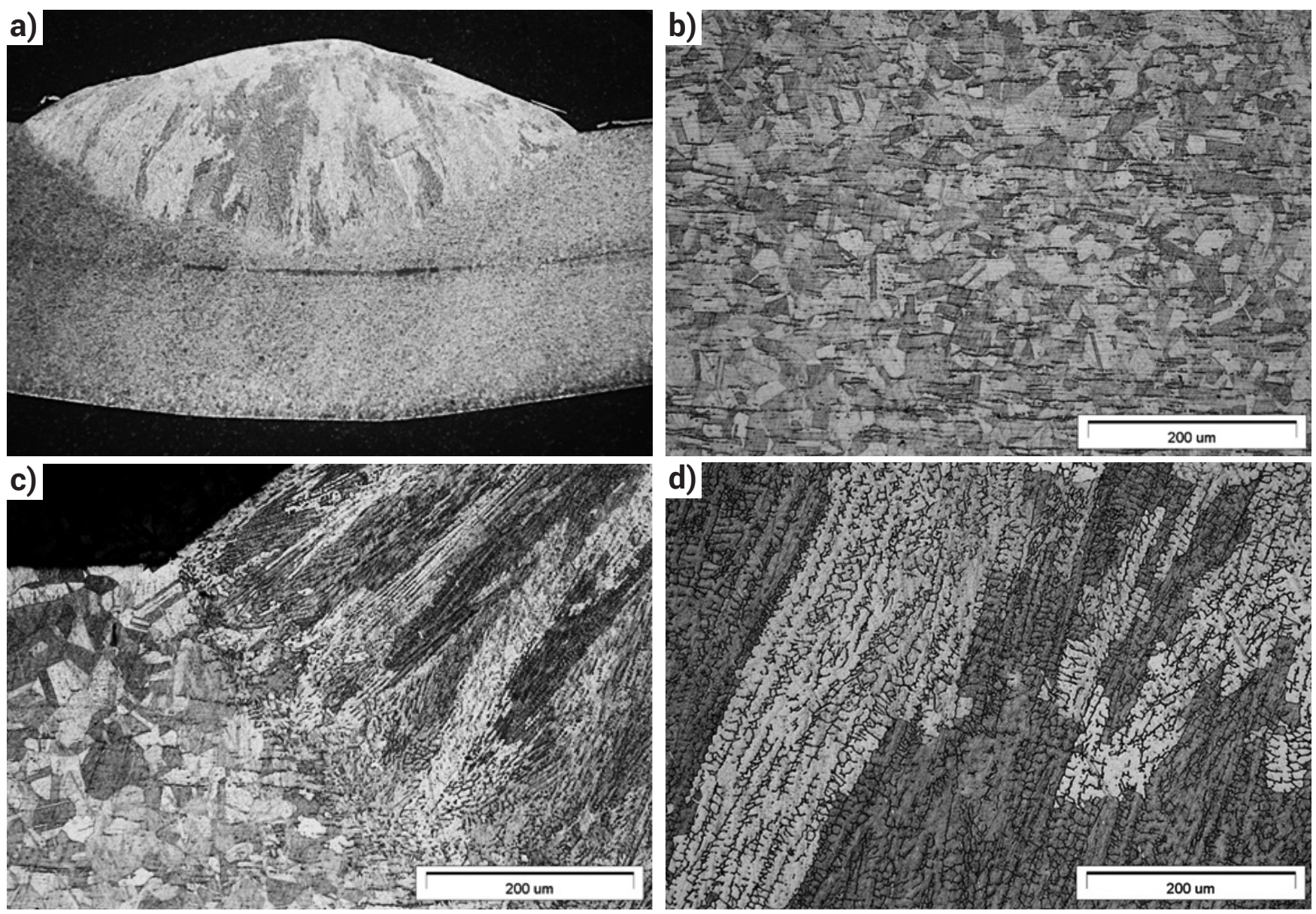

Rys. 3. Stal 304: a) makrostruktura złącza (SM), b) materiał rodzimy (LM), c) linia wtopienia (LM), d) spoina (LM)

Fig. 3. 304 steel: a) macrostructure of welded joints (SM), b) base material (LM), c) fusion line (LM), d) welded joint (LM)
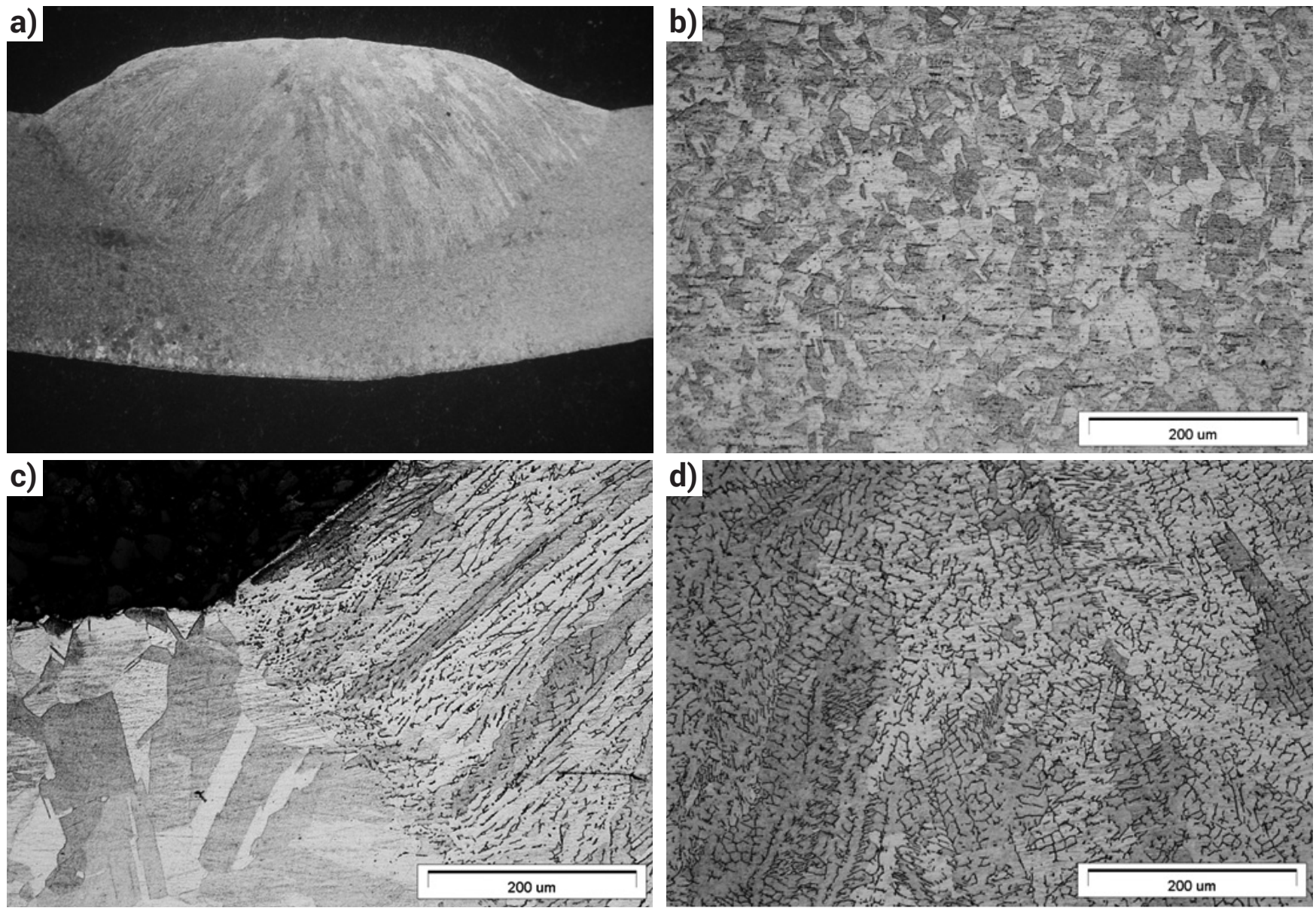

Rys. 4. Stal 304H: a) makrostruktura złącza (SM), b) materiał rodzimy (LM), c) linia wtopienia (LM), d) spoina (LM)

Fig. 4. $304 \mathrm{H}$ steel: a) macrostructure of welded joints (SM), b) base material (LM), c) fusion line (LM), d) welded joint (LM) 


\section{Wyniki badań}

Obserwacje mikrostruktury prowadzono na mikroskopie stereoskopowym SZX9 (SM) przy powiększeniach do 50x, mikroskopie świetlnym Olympus GX71 (LM) przy powiększeniach do 200x w technice pola jasnego. Wykonano również badania struktury na elektronowym mikroskopie skaningowym JEOL JCM-6000 Neoscope II (SEM). Rejestracji obrazów dokonano w technice elektronów wtórnych SE, przy powiększeniu do 1500x i napięciu przyspieszającym wiązkę elektronów $15 \mathrm{keV}$. Uzupełnieniem badań była mikroanaliza składu chemicznego wykonana metodą EDS w strefie pęknięcia.
Makrostruktura ujawnia prawidłowy układ połączenia spawanego, w którym wyróżnić można materiał rodzimy, strefę wpływu ciepła oraz spoinę (rys. 3a, 4a). Materiał rodzimy zarówno stali 304, jak i 304H charakteryzuje się strukturą poligonalnych ziaren austenitu, w których obserwowano liczne bliźniaki (rys. 3b, 4b). Na linii wtopienia, na nadtopionych ziarnach austenitu narastają kryształy spoiny zgodnie z kierunkiem odprowadzenia ciepła (rys. 3c, 4c). W spoinie obserwowano kierunkowe kryształy austenitu ze słabo rozwiniętymi ramionami (rys. 3d, 4d). Na podstawie mikroanalizy składu chemicznego z obszaru spoiny i materiału rodzimego stwierdzono, że skład chemiczny spoiny jest zbliżony do materiału rodzimego.

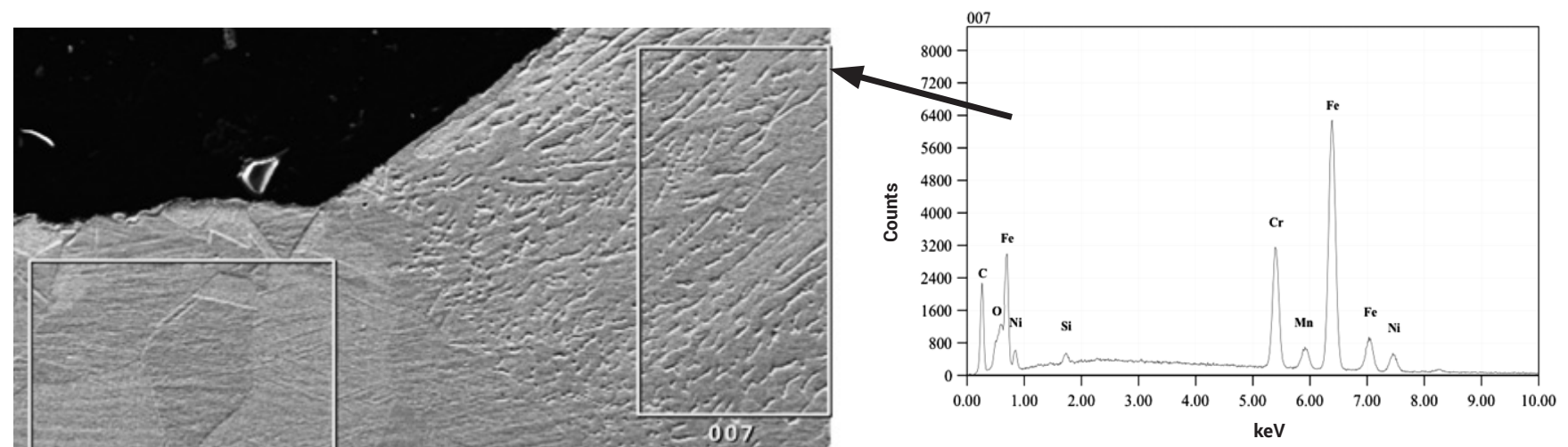

\begin{tabular}{|c|c|c|c|c|c|}
\hline Punkt & $\mathrm{Si}$ & $\mathrm{Cr}$ & $\mathrm{Mn}$ & $\mathrm{Fe}$ & $\mathrm{Ni}$ \\
\hline 006 & 0.51 & 18.88 & 0.69 & 72,12 & 7.80 \\
\hline 007 & 0.66 & 19.49 & 0.68 & 70.49 & 8.69 \\
\hline
\end{tabular}

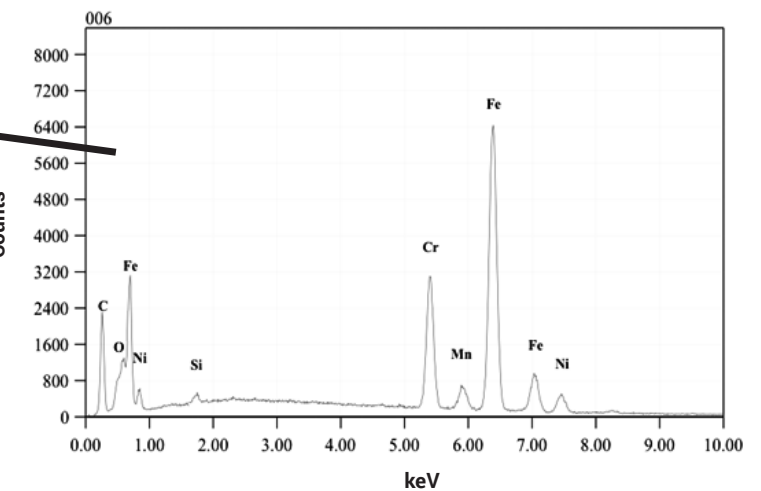

Rys. 5. Wyniki mikroanalizy EDS z obszaru materiału rodzimego i spoiny stali $304 \mathrm{H}$

Fig. 5. Results of the chemical composition microanalysis at base material and welded joint $304 \mathrm{H}$ steel
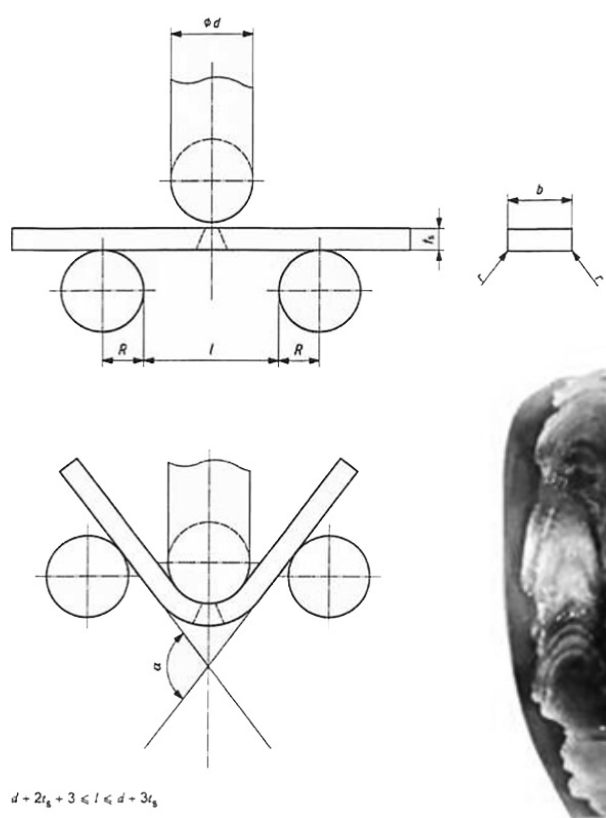
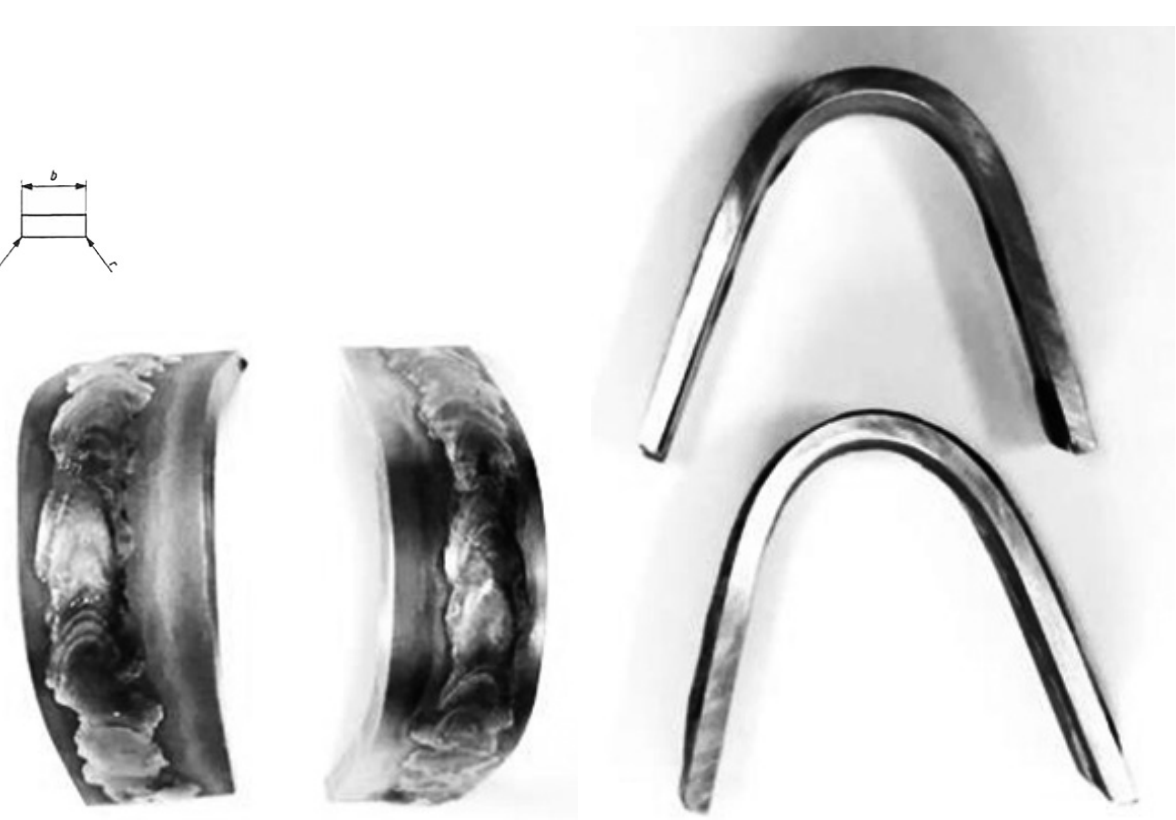

Rys. 6. Wyniki próby gięcia złączy w roztworze $40 \%$ kwasu siarkowego (VI) i siarczanie (VI) żelaza (III): a) Schemat próby gięcia, b) próbki po gięciu

Fig. 6. The test results of bending joints in a solution of $40 \%$ sulfuric acid (VI) and iron (III) sulfate; a) bending pattern, b) specimen after bending 
Analiza wyników obserwacji struktury lica stali 304 w obszarze najbardziej odkształconym po wytrzymaniu przez $24 \mathrm{~h}$ w roztworze kwasu ujawniła powierzchniowe roztrawienie po granicach ziarn, co może wskazywać na obniżenie odporności na korozję międzykrystaliczną (rys. 7b). W obszarach nieodkształconych nie obserwowano roztrawień, co potwierdza wysoką odporność na korozję międzykrystaliczną materiału rodzimego (rys. 7a). Na powierzchni lica ujawniono warstwę pasywną (rys. 7a). Jest to prawdopodobnie tlenek chromu $\mathrm{Cr}_{2} \mathrm{O}_{3}$ i żelaza $\mathrm{Fe}_{3} \mathrm{O}_{4}$, które powstają w wyniku reakcji
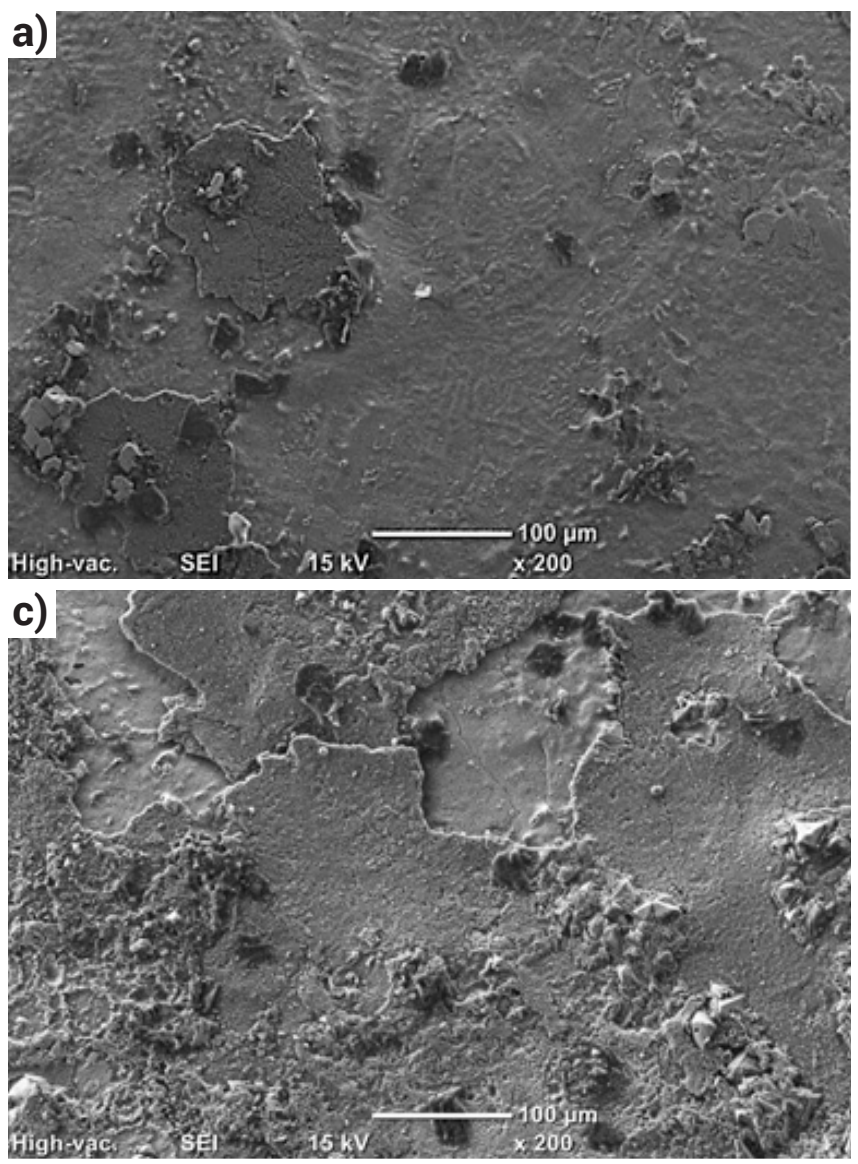

utleniania powierzchni (rys. 8). Podobne zjawiska wystąpiły w przypadku stali 304H (rys 7c, 7d).

Badania mikrostruktury w obszarze lica napoiny na zgładzie poprzecznym nie ujawniły mikropęknięć po granicach ziaren w głąb materiału (rys. 9). Oznacza to, że obserwowane na powierzchni roztrawienia nie powodują korozji międzykrystalicznej złącza spawanego i nie mają znaczącego wpływu na odporność konstrukcji na działanie agresywnego środowiska związanego z redukcyjnymi roztworami kwasu siarkowego.
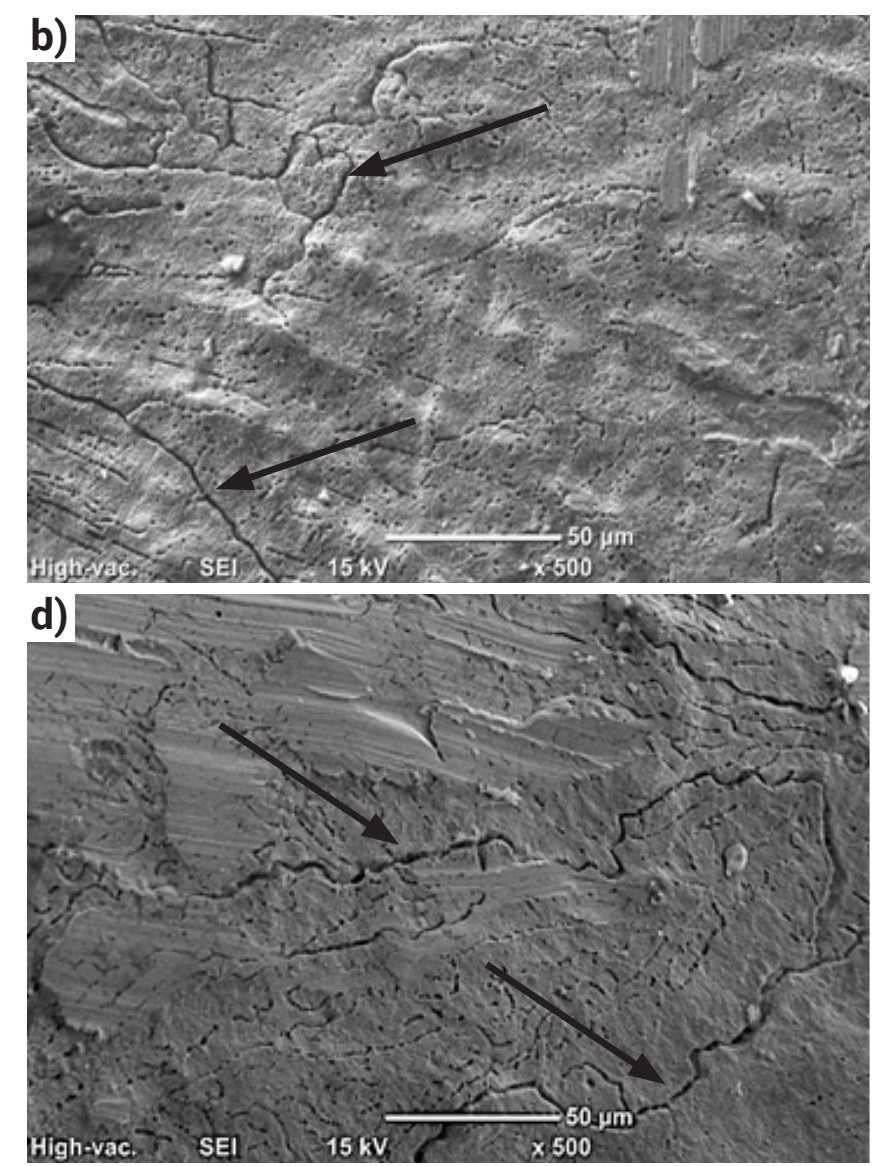

Rys. 7. Powierzchnia spoiny: a) stal $304 \mathrm{w}$ miejscu nienarażonym na zginanie, b) stal $304 \mathrm{w}$ obszarze zgięcia, c) stal 304H w miejscu nienarażonym na zginanie, d) stal $304 \mathrm{H}$ w obszarze zgięcia

Fig. 7. Weld surface: a) steel 304 in a place not bent, b) steel 304 in the bending area, c) $304 \mathrm{H}$ steel in a non-bending site, d) $304 \mathrm{H}$ steel in the bending area

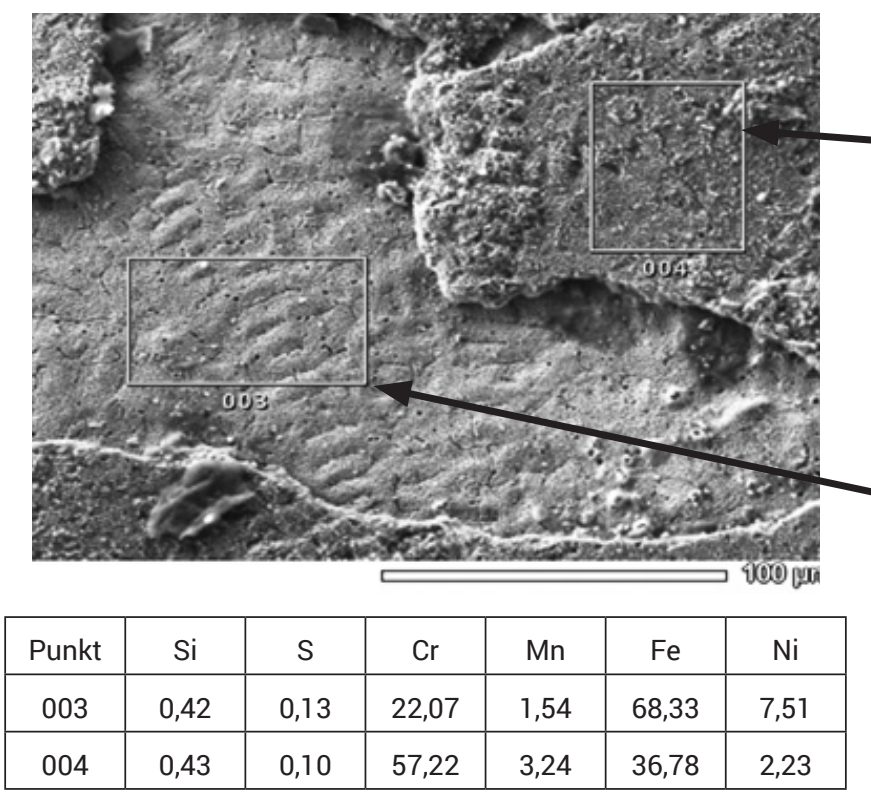

Rys. 8. Analiza EDS w miejscu zgięcia spoiny na stali 304H

Fig. 8. EDS analysis at the bending point of the weld on $304 \mathrm{H}$ steel
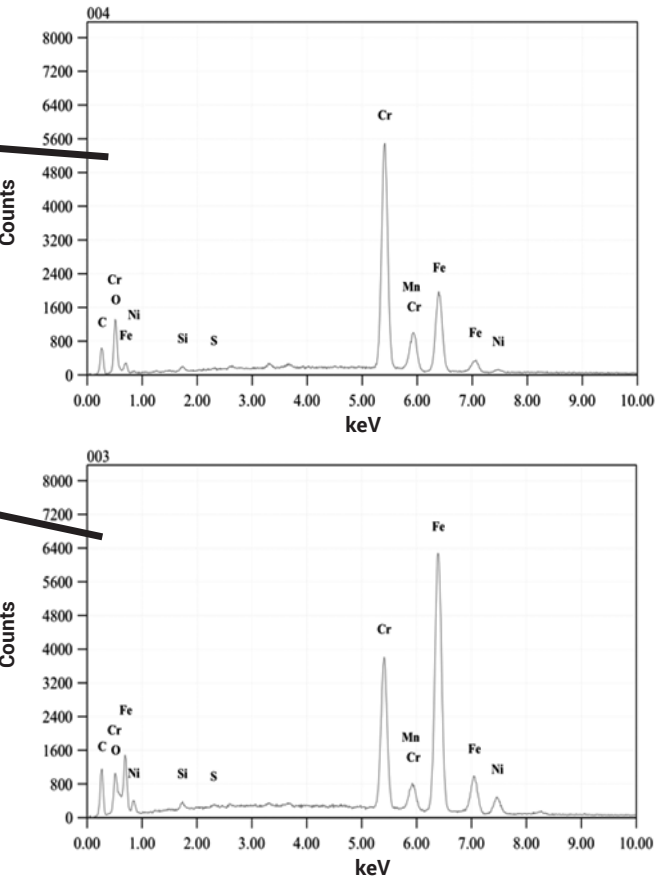

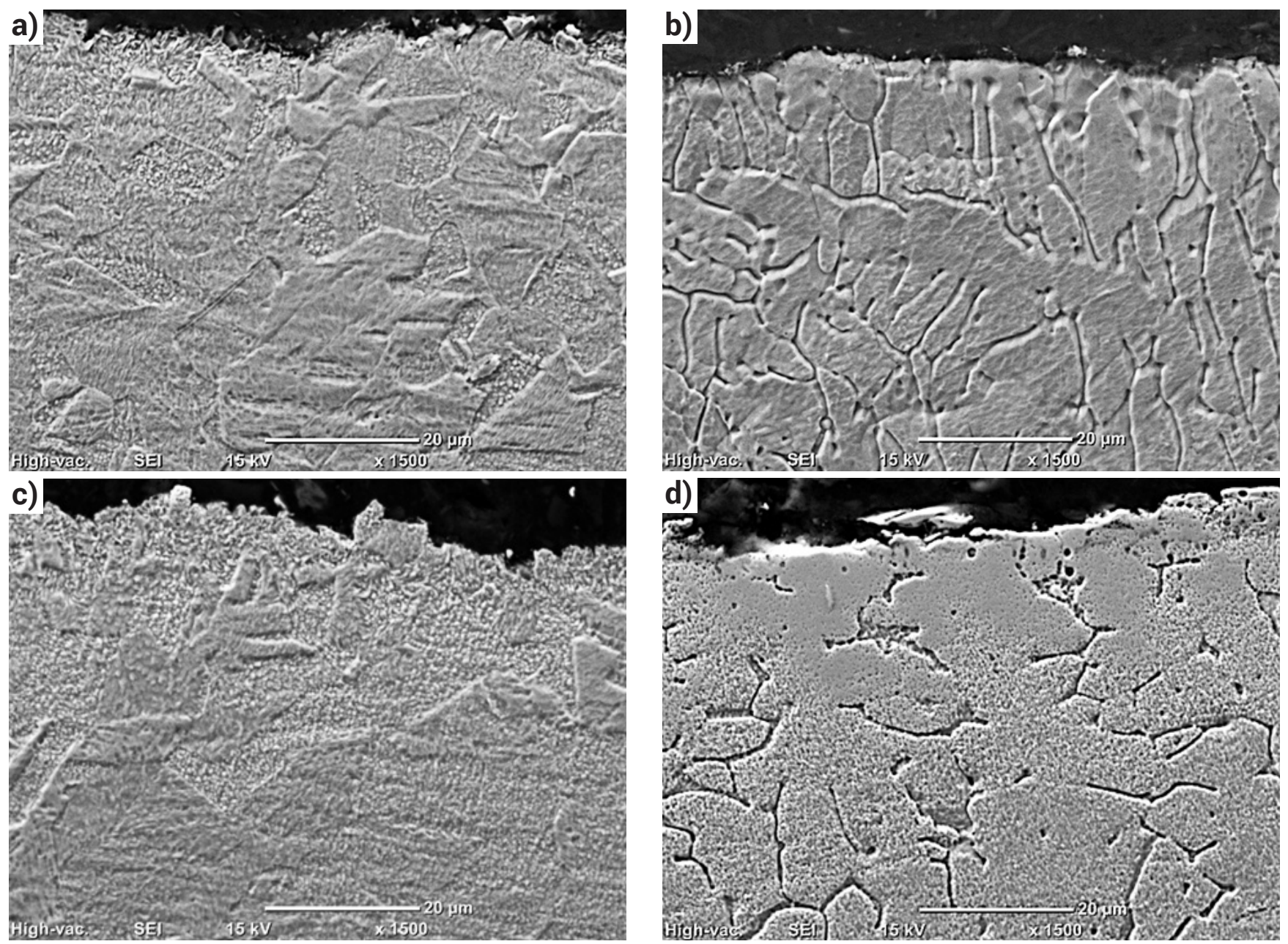

Rys. 9. Mikrostruktura badanego materiału: a) mikrostruktura materiału rodzimego stali 304, b) mikrostruktura spoiny stali 304 , c) mikrostruktura materiału rodzimego stali $304 \mathrm{H}$, d) mikrostruktura spoiny stali $304 \mathrm{H}$, SEM

Fig. 9. Microstructure of the test material: a) microstructure of base material 304 steel, b) microstructure of welded joint 304 steel,

c) microstructure of base material $304 \mathrm{H}$ steel, d) microstructure of welded joint $304 \mathrm{H}$ steel

\section{Podsumowanie}

Badania odporności na korozję międzykrystaliczną po próbie zginania zgodnie z normą PN-EN ISO 3651-2 wykazały, że napoiny wykonane na stali 304, jak i 304H wykazują dobrą odporność na działanie środowiska korozyjnego, a w szczególności na korozję międzykrystaliczną. Obserwacja zgładów metalograficznych w obszarze materiału rodzimego, strefy wpływu ciepła i spoiny nie ujawniła mikropęknięć rozchodzących się po granicach ziaren, a jedynie powierzchniowe roztrawienia po granicach. Natomiast rozciągana powierzchnia lica w obszarze zginania charakteryzowała się popękaną warstwą tlenków, w tym $\mathrm{Cr}_{2} \mathrm{O}_{3}$ i $\mathrm{Fe}_{3} \mathrm{O}_{4}$, który stanowi warstwę pasywującą. To zjawisko może zwiększać skłonność do korozji elektrochemicznej złącza spawanego.

\section{Literatura}

[1] Decyzja Parlamentu Europejskiego i Rady nr 2009/406/WE z dnia 23 kwietnia 2009 r. w sprawie wysiłków podjętych przez państwa członkowskie, zmierzających do zmniejszenia emisji gazów cieplarnianych w celu realizacji do roku 2020 zobowiązań Wspólnoty dotyczących redukcji emisji gazów cieplarnianych.

[2] Surowska B.: Wybrane zagadnienia z korozji i ochrony przed korozją, Lublin 2002

[3] H. T. Lee, J. L. Wu: Corrosion, Science 51, 2009, pp. 733-743.

[4] Brózda J., Czaja G.: Żarowytrzymała stal T92/P92, jej spawanie i własności złączy spawanych, Przegląd Spawalnictwa 2014, nr 4, s. 51-61.

[5] Adamiec J., Tasak E., Tuz L., Pańcikiewicz K.: Ocena mikrostruktury wybranych stopów niklu, Przegląd Spawalnictwa 2014.

[6] Stachyra, G.: Korozja naprężeniowa i międzykrystaliczna na przykładzie wybranych zbiorników ciśnieniowych. Dozór Techniczny, Czasopismo Federacji Stowarzyszeń Naukowo-Technicznych NOT.

[7] Baszkiewicz J., Kamiński M.: Podstawy korozji materiałów, Oficyna Wyd Politechniki Warszawskiej, Warszawa 1997.

[8] Dobrzański L. A.: Metaloznawstwo i obróbka cieplna stopów metali, Wyd. Politechniki Śląskiej, Gliwice 1995

[9] Hernas A., Kościelniak B., Hajda J.: Mikrostruktura i właściwości złączy spawanych z nadstopu niklu Inconel $740 \mathrm{H}$ po starzeniu w $750^{\circ} \mathrm{C}$, w: Charakterystyki nowej generacji materiałów dla energetyki, pod red. A. Hernasa, Bełchatów, 2015, s. 175-176.

[10] pr. zb. pod red. Shreira L. L.: Korozja, WNT Warszawa 1966, t.1.

[11] PN-EN ISO 5173: 2010. Badania niszczące spoin w materiałach metalowych - Badania na zginanie. 